\title{
Teacher's questioning skills and students' responses in science subject based on parenting style perspectives
}

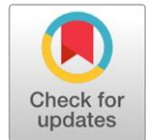

Nurhaty Purnama Sari a,1,*, Wilda Fasim Hasibuan a,2

a Department of Biology Education, Faculty of Teacher Training and Education, Universitas Riau Kepulauan, Jl. Batu Aji 99, Batu Aji District, Batam,

Riau Islands 29424, Indonesia

${ }^{1}$ nurhatypurnamasari@gmail.com*; ${ }^{2}$ wildahasibuan@hotmail.com;

* corresponding author

\begin{tabular}{|c|c|}
\hline ARTICLE INFO & ABSTRACT \\
\hline $\begin{array}{l}\text { Article history } \\
\text { Received November 13, } 2018 \\
\text { Revised February 13, } 2019 \\
\text { Accepted February 23, } 2019 \\
\text { Published March 05, } 2019 \\
\text { Keywords } \\
\text { Parenting style } \\
\text { Questioning skills } \\
\text { Students' response }\end{array}$ & $\begin{array}{l}\text { Parenting styles were considered as one of important factors in determining students' } \\
\text { performance in science, especially in elementary school. This study aimed to explain } \\
\text { the teacher's questioning skills and student' responses in science subject based on } \\
\text { parenting styles in elementary schools in Batam. This descriptive qualitative research } \\
\text { was conducted in the first semester of academic year } 2017 / 2018 \text { and involved four } \\
\text { classroom teachers and } 109 \text { students. The data collection techniques used were } \\
\text { questionnaire and observation. The findings of this study showed that the teacher } \\
\text { questioning skills in science subject in elementary schools in Batam were good enough. } \\
\text { Meanwhile, the highest frequent parenting style used was authoritarian (94.83\%). Yet } \\
\text { the style led the students to be less active in learning processes. }\end{array}$ \\
\hline
\end{tabular}

\section{INTRODUCTION}

Science teachers are one of the determinants of science learning quality in the current era. Science teachers must be able to design learning that optimally teaches the concepts of science. A good understanding of scientific concepts and being able to practice various scientific concepts is the main element that must be mastered when teaching those various science concepts.

When teaching various scientific concepts, the interaction between teacher and students during the teaching and learning process plays a major role. One of the ways teacher interaction with students is through giving questions. Questioning is an essential strategy for effective communication in academic settings (Ziyaeemehr, 2016) and is a crucial activity in the teaching and learning process (Almeida, 2012). Therefore, improving the questioning strategy can improve the quality of interactions in the learning process (Hanum, 2016).

The teacher can give questions to students in each learning activity. Giving these questions can be done at the beginning, middle, or closing the learning activities. In giving these questions, some teachers can 
provide quality questions, some of the other teachers are less able to arrange good questions. The quality of the question is determined by the questioning skills mastered by the teacher.

Questioning is an important skill in teaching science (Çakmak, 2009). The skill of giving questions is related to teacher communication skills. Good communication skills will direct the learning process to be more qualified (Fashiku, 2017). In fact, the quality of the teacher in giving questions can significantly improve the quality of learning (Napp, 2017). Through good questioning and communication skills, students can be provoked to increase their curiosity, stimulate their imagination, and be motivated to learn new knowledge that they have not mastered (Omar, 2009). Through asking, the teacher can lead the way of thinking of their students; the teacher can also know the level of understanding of students to elaborate on students' answers to other ideas.

In its context and type, the question level has the most important role in the development of cognitive, affective and psychomotor abilities in students. In addition to measuring student success, questions should make students think freely about the answers to the questions asked by the teacher. Moreover, it is important to understand what components questions should include for students to have meaningful learning. Good questions are defined as facilitating learners' thoughts centered on their experience and subsequently leading to creative thinking (Kim, 2015; Lee et al., 2011).

Sometimes, the teacher immediately gives questions to students randomly. However, the teacher can also determine which student candidate will answer the questions that will be given by the teacher. The situation can be helpful to allow some time for students to think about and to present the answers (Ragawanti, 2010). In addition, students also sometimes cannot answer questions from the teacher. In these conditions, the teacher must be able to encourage them rather than criticize or not even pay attention to the answers of these students (Yang, 2017).

In addition to the ability to ask, the parenting style is indicated to also affect the academic achievement of a student. In addition, there are questions about the relationship between student responses to teacher questions and parenting styles. Each parenting style is a different impact on students during the learning process. Family roles are very important in building student achievement, determining how students socialize themselves and performing at school. Furthermore, it was said that parenting was related to the average scores of students, the presence of students in the class, a positive attitude and completing education in college. Moreover, students' responses in answering teacher questions were also reported regarding parenting styles in their families (Toldson \& Lemmons, 2013). Therefore, various studies inform that parenting style is one of the factors that influence the academic achievement of a student (Bacus, 2014; Ishak, Low, \& Lau, 2012; Kenney, Lac, Hummer, Grimaldi, \& LaBrie, 2015; Necşoi, Porumbu, \& Beldianu, 2013; Warren, Locklear, \& Watson, 2018).

Parenting styles provide space for children to develop themselves according to their interests, talents, abilities, and emotions. Parenting style can be categorized into two: control and warmth. In some types of parenting, parents have both characteristics. Authoritarian parenting usually has higher control; parental orientation is proven when the child is obedient to the command and the low level of warmth that parents give to their child. In democratic parenting, control and warmth are divided into two equal parts so that everything is balanced. Conversely, on permissive parenting, the level of warmth is high, but the control given is very low; in this case, the child is the king of his parents. The last type of parenting is the type of neglect, where there is no control, warmth, or support from parents (Baugh \& Davis, 2016; Yazdani \& Daryei, 2016).

In relation to student responses to teacher's question, it is predicted that students who are shy to ask a question may come from families with authoritarian parenting backgrounds. In contrast, students who always raise their hands to answer the questions come from families with democratic upbringing. Meanwhile, students who are indifferent when the teacher asks questions, generally come from parents who have permissive and neglect styles. The study of the influence of parenting style on student academic achievements is an interesting topic. However, this study is still rarely done in educational research in Indonesia. Furthermore, the study of parenting styles that are associated with student responses to teacher questions during learning is also rarely studied. Some previous studies only examined the effect of parenting style on student attitudes (Bacus, 2014), academic achievement (Ishak et al., 2012), academic success (Toldson \& Lemmons, 2013), and self-esteem (Zakeri \& Karimpour, 2011). Therefore, it is necessary to conduct studies that can reveal students' responses to the questions given in the classroom and how they relate to the parenting style of the students. 


\section{METHOD}

This research was a descriptive study that attempts to identify teacher's questioning skills and student' responses and parenting style perspective in a science subject. The subjects of this study were four class teachers and 109 elementary school students in Batam. Some instruments were used to collect data on this research. Data on question skills were collected with the help of instruments in the form of observation sheets. The observation sheet was used by observers to collect data on teacher questioning activities during the science learning process. The observation instrument focused on four aspects of questioning, namely basic questioning skills, advanced questioning skills, questioning techniques, and types of teacher questions. Furthermore, student response data were obtained with the help of instruments in the form of observation sheets as well. Through these observations sheet, the observer records students' responses to the questions given by the teacher during the learning process.

Parenting style data was collected using a Parenting Practices Questionnaire Construct (PPQC) developed by Robinson, Mandleco, Olsen, \& Hart (1995). According to PPQC, occurred 3 types of parenting style and each categorization. The first, authoritative items divided into four characteristics: 1) warmth and involvement; 2) reasoning/induction; 3) democratic participation' and 4) good-natured/easy going. The second, authoritarian item split of four dimensions: 1) verbal hostility; 2) corporal punishment; 3) nonreasoning, punitive strategies; and 4) directiveness. The last, permissive items consisted of three measures: 1) lack of follow through; 2) ignoring misbehavior; and 3) self-confidence. The PPQC consisted of 133 items. However, upon validity and reliability testing, the questionnaire consisted of 27 authoritarian parenting items, 20 democratic parenting items, and 15 permissive parenting. The results of the validity test informed that the $r$ values obtained was 0.3 and Cronbach Alpha values on authoritative items, authoritarian items, and permissive items amounted to $0.91 ; 0.86$; and 0.75 respectively. Questionnaires were given to more than 120 parents, but the returned number was 109 pieces.

Data from research results that have been collected were then analyzed. Data were analyzed descriptively. Data on question skills and student responses to teacher questions were analyzed descriptively qualitatively, while parenting style data were analyzed using descriptive statistics which included mean and percentage.

\section{RESULTS AND DISCUSSION}

The teacher's skill in asking plays a key role in teacher and student interaction during the learning process. In general, questioning skills are divided into two, namely basic and advanced questioning skills. The results of observations of basic questioning skills are presented in Table 1, while advanced questioning skills are presented in Table 2. Basic questioning skills are skills that have some basic abilities that need to be applied in asking the type of question. Based on Table 1, teachers in Batam elementary school could do it.

Table 1. Teacher's questioning skills in Batam elementary schools

\begin{tabular}{lllll}
\hline \multicolumn{1}{c}{ Components } & \multicolumn{1}{c}{ Teacher A } & Teacher B & Teacher C & Teacher D \\
\hline Stating clear and concise questions & Implemented & Implemented & Implemented & Implemented \\
Giving reference & $\begin{array}{l}\text { Information was not so much } \\
\text { delivered by the teacher }\end{array}$ & Implemented & Implemented & Not yet \\
Providing Concentration & Implemented & Implemented & Implemented & Implemented \\
Taking turn & Implemented & Implemented & Implemented & Implemented \\
Balanced Distribution & Implemented & Implemented & Implemented & Implemented \\
Giving time to think & Implemented & Implemented & Implemented & Implemented \\
Giving guidance & Implemented & Implemented & Implemented & Implemented \\
\hline
\end{tabular}

Based on previous research reports, the teacher's skills in asking are important skills that can improve student learning (Hamiloglu \& Temiz, 2012). In giving questions, the teacher must encourage students to actively ask. The teacher must be able to optimize academic interaction and communication during the learning process. In giving questions, the teacher must be able to provide opportunities for all students to answer questions. Thus, no student dominates too much. Teachers sometimes also have to give time to students before they answer questions. Giving time gives an opportunity for students to think about the answers they will express. After that, the teacher must appreciate the answers to their students. All of these skills are basic questioning skills that must be possessed by the teacher. 
Table 2. Advanced questioning skills of elementary school teachers in Batam

\begin{tabular}{|c|c|c|c|c|}
\hline Advanced questioning skills & Teacher $\mathbf{A}$ & Teacher B & Teacher C & Teacher D \\
\hline $\begin{array}{l}\text { Changing cognitive level demands in } \\
\text { answering questions, from the lowest to the } \\
\text { highest level }\end{array}$ & Implemented & Implemented & Implemented & Implemented \\
\hline $\begin{array}{l}\text { Ordering the sequence of questions, from the } \\
\text { simplest questions followed by questions with } \\
\text { complex organization }\end{array}$ & Implemented & Implemented & Implemented & $\begin{array}{l}\text { The teacher } \\
\text { gave } \\
\text { advanced } \\
\text { type of } \\
\text { questions. }\end{array}$ \\
\hline $\begin{array}{l}\text { Use tracking questions with various techniques } \\
\text { The occurrence of increased interaction, by }\end{array}$ & $\begin{array}{l}\text { Not yet } \\
\text { Implemented }\end{array}$ & $\begin{array}{l}\text { Not yet } \\
\text { Implemented }\end{array}$ & $\begin{array}{l}\text { Not yet } \\
\text { Implemented }\end{array}$ & $\begin{array}{l}\text { Implemented } \\
\text { Implemented }\end{array}$ \\
\hline
\end{tabular}
asking other students to provide answers to the same question.

Furthermore, the study results pointed out that most teachers needed to improve advanced questioning skills, especially in changing the cognitive level demands in giving questions, from the lowest level to the highest level (Table 2). Besides, teachers did negative habits in asking questions such as repeating their own questions or repeating student answers, answering their own questions, often asking questions that invite simultaneous answers, and asking multiple questions at the same time.

Table 3. Questioning techniques of elementary school teachers in Batam

\begin{tabular}{|c|c|c|c|c|}
\hline Techniques & Teacher A & Teacher B & Teacher C & Teacher D \\
\hline Waiting technique & Implemented & Implemented & Implemented & Implemented \\
\hline Reinforcement technique & $\begin{array}{l}\text { Teacher said yes } \\
\text { and correct to } \\
\text { each of the } \\
\text { student's correct } \\
\text { answer. }\end{array}$ & $\begin{array}{l}\text { Teacher said correct } \\
\text { and gave applause } \\
\text { for the student's } \\
\text { correct answer }\end{array}$ & $\begin{array}{l}\text { Teacher said thank } \\
\text { you, great, good } \\
\text { job, and give } \\
\text { applause. }\end{array}$ & $\begin{array}{l}\text { Teacher asked other } \\
\text { students to give } \\
\text { encouragement and } \\
\text { applause after the } \\
\text { completion of student } \\
\text { presentation }\end{array}$ \\
\hline Prompting and probing techniques & Implemented & Implemented & Implemented & Not yet \\
\hline
\end{tabular}

Table 4. Type of question made by elementary school teachers in Batam

\begin{tabular}{|c|c|c|c|c|}
\hline Types of Questions & Teacher A & Teacher B & Teacher C & Teacher D \\
\hline $\begin{array}{l}\text { Types of questions based on student } \\
\text { thinking levels. }\end{array}$ & $\begin{array}{l}\text { Dominated by } \\
\text { questions on facts } \\
\text { (low level) and a } \\
\text { little bit of } \\
\text { understanding } \\
\text { question. }\end{array}$ & $\begin{array}{l}\text { Dominated by } \\
\text { questions on facts } \\
\text { (low level) and a } \\
\text { little bit of } \\
\text { understanding } \\
\text { question. }\end{array}$ & $\begin{array}{l}\text { Dominated by } \\
\text { questions on facts } \\
\text { (low level) and a } \\
\text { little bit of } \\
\text { understanding } \\
\text { question. }\end{array}$ & $\begin{array}{l}\text { Questions were } \\
\text { already in } \\
\text { comprehension } \\
\text { and analysis } \\
\text { levels. }\end{array}$ \\
\hline $\begin{array}{l}\text { Types of question according to its width and } \\
\text { narrowness }\end{array}$ & $\begin{array}{l}\text { The teacher } \\
\text { performed a } \\
\text { narrow type of } \\
\text { question that } \\
\text { consisted of } \\
\text { memorizing or } \\
\text { remembering } \\
\text { information. }\end{array}$ & $\begin{array}{l}\text { The teacher } \\
\text { performed a } \\
\text { narrow type of } \\
\text { question that } \\
\text { consisted of } \\
\text { memorizing or } \\
\text { remembering } \\
\text { information. }\end{array}$ & $\begin{array}{l}\text { The teacher } \\
\text { performed two } \\
\text { types of } \\
\text { questions; the } \\
\text { first was narrow } \\
\text { question in } \\
\text { memorizing or } \\
\text { remembering } \\
\text { information. The } \\
\text { second was the } \\
\text { broad open } \\
\text { question. }\end{array}$ & $\begin{array}{l}\text { Teacher D } \\
\text { implemented a } \\
\text { broad type of } \\
\text { question }\end{array}$ \\
\hline $\begin{array}{l}\text { Types of questions based on types of } \\
\text { answers given }\end{array}$ & $\begin{array}{l}\text { More dominated } \\
\text { by convergent } \\
\text { type of questions }\end{array}$ & $\begin{array}{l}\text { More dominated } \\
\text { by convergent } \\
\text { type of questions }\end{array}$ & $\begin{array}{l}\text { More dominated } \\
\text { by convergent } \\
\text { type of questions }\end{array}$ & $\begin{array}{l}\text { Convergent and } \\
\text { divergent types of } \\
\text { questions. }\end{array}$ \\
\hline $\begin{array}{l}\text { The questions were based on Bloom's } \\
\text { taxonomy }\end{array}$ & $\begin{array}{l}\text { 1) remember, 2) } \\
\text { understand }\end{array}$ & $\begin{array}{l}\text { 1) remember, 2) } \\
\text { understand }\end{array}$ & $\begin{array}{l}\text { 1) remember, 2) } \\
\text { understand }\end{array}$ & $\begin{array}{l}\text { 1) remember, 2) } \\
\text { understand, 3) } \\
\text { apply, and 4) } \\
\text { analyze. }\end{array}$ \\
\hline
\end{tabular}


Then, based on Table 3, at overall it was suggested that the technique of question done by the teachers was considered good at waiting technique (giving enough time to think) and reinforcement technique. In probing techniques, most teachers need to improve this area. Probes are based on student responses. The initial response of students may be superficial. The instructor needs to use a questioning strategy called probing to make students explore initial comments. Probes are useful in getting students more involved in critical analysis of their own and other students' ideas. If the student does not provide a complete answer, he or she may know a partial answer. In some cases, even though the question is perfectly clear to the teacher; it might need to be restated or broken down into smaller pieces. The teacher should not accept "I don't know" as the final response (Etemadzadeh, Seifi, \& Far, 2013; Kim, 2015).

Furthermore, based on the type of question made by the teacher during the learning process that presented in Table 4, there were types of questions expressed by teachers. Most of which were factual, narrow, convergent, and in the understanding level. From other study results that these questions were a convergent question. It is explained that both divergent and convergent questions can be used to attract students" interest and attention, but it might be more reasonable to use convergent questions which can easily be prepared to direct students" attention toward a specific point. While convergent questions are posed to remind students of certain facts and information, divergent questions are used to induce higher-level thinking. In this sense, it can be claimed that teachers have misconceptions about convergent and divergent questions.

Wrong questions for wrong aims might lead to wrong results. In addition, teachers" statements that they ask questions mostly to attract students" interest and attention might provide information about how the lesson is taught. Convergent questions should be used mostly to make students do critical and creative thinking for problem-solving. The teachers stated that they mostly used divergent questions to improve students' higher-level thinking skills such as consideration and reasoning, to perform learning, and to improve active learning, creative thinking, emotions, and thoughts. Although all these mentioned indicate correct uses, teachers further stated that they use divergent questions to determine whether students comprehend certain concepts, to activate their prior knowledge and to ensure that students express themselves. However, using convergent questions for the previously-mentioned purposes is easier and more reasonable (Bulent et al., 2016; Çakır \& Cengiz, 2016). Therefore, based on the results of the study, the type of Batam elementary school teacher questions needs to be improved. Moreover, the study explained that teachers are expected to ask higher-level questions for higher-level learning. In addition to improving students" critical thinking skills, high-level questioning stimulates students" active participation and facilitates learning (Bulent et al., 2016; Nalole, 2010).

Table 5. Student's responses toward teacher's question in elementary school of Batam.

\begin{tabular}{|c|c|c|c|c|}
\hline Student's Responses & Teacher $\mathbf{A}$ & Teacher B & Teacher C & Teacher D \\
\hline Categories of student's responses & $\begin{array}{l}\text { Scientific, half } \\
\text { scientific, } \\
\text { misconception, } \\
\text { zero }\end{array}$ & $\begin{array}{l}\text { Scientific, half } \\
\text { scientific, zero, } \\
\text { wrong }\end{array}$ & $\begin{array}{l}\text { Scientific, half } \\
\text { scientific, zero, } \\
\text { wrong }\end{array}$ & Half science, zero \\
\hline $\begin{array}{l}\text { Students could not answer (when teacher } \\
\text { asked to all students) }\end{array}$ & No & Yes & Yes & Yes \\
\hline Students gave cordial answers. & Often & Often & There were some & None \\
\hline $\begin{array}{l}\text { Students were appointed but unable to } \\
\text { answer }\end{array}$ & Yes & Yes & Yes & $\begin{array}{l}\text { Students thought } \\
\text { about the answer } \\
\text { and then followed } \\
\text { by an answer from } \\
\text { the teacher } \\
\text { himself. }\end{array}$ \\
\hline $\begin{array}{l}\text { Students were appointed and was able to } \\
\text { answer }\end{array}$ & Yes & Yes & Yes & None. \\
\hline $\begin{array}{l}\text { Students were confused to provide a correct } \\
\text { answer }\end{array}$ & Yes & Yes & Yes & Yes \\
\hline Students showed to answer the questions & Yes & Yes & Yes & None \\
\hline Students questions to the teacher & None & Some & Some & Many \\
\hline
\end{tabular}

Student responses to the questions given by the teacher during learning were also studied in this study. The student response data is presented in Table 5. The results shown in Table 5 of the study indicated: 1) question answered by short scientific answers. It meant that the teacher used low-level questions in the learning process (Kim, 2015); 2) students often answered more simultaneous rather than showing 
themselves. It is proved question's technique of teachers needed to be improved; 3 ) only a few students asked the question, even though still much to be explained in real phenomena. It happened because students were familiar with low-level questions that only need to be memorized (Bulent et al., 2016).

Then, according to the research problems presented in the introduction, this study also examined the parenting style of students involved as the subject of this study. From the number of questionnaires returned, it was found that 83 parents had authoritarian parenting, 17 parents were permissive, and 9 parents educated children with an authoritative parenting style. The data is presented in graphical form in Figure 1.

In this study, parenting was treated as an alternative analysis of student responses to teacher questions, consisting of 1) student answers were dominated by scientific answers, half scientific, zero and wrong; 2) not many students could not answer (when the teacher asked all students; 3) students gave more answers simultaneously; 4) few students were appointed but were unable to answer; 5) many designated students were able to answer; 6) students were confused to give the right answers to practical learning, and 7) few students showed themselves to answer questions and few students asked the teacher.

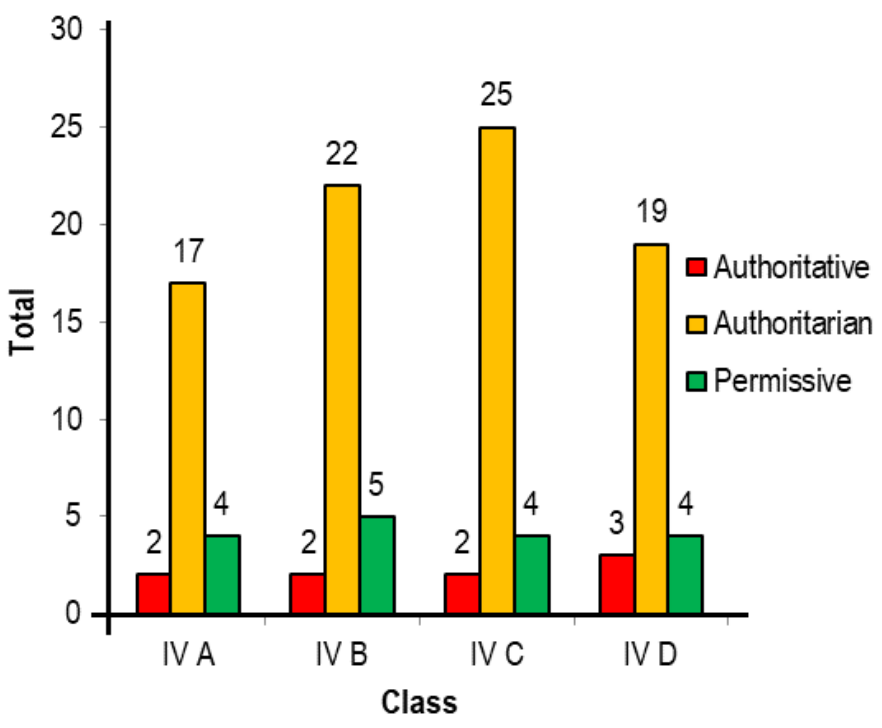

Figure 1. The distribution data of parenting style

The seventh point from the results of the study portrayed: very few students showed off to answer questions from the teacher. This was in line with the results of the questionnaire that $94.83 \%$ of parenting style was authoritarian, $18.53 \%$ was permissive parenting, and $9.81 \%$ was democratic parenting. Authoritarian parenting produced children who are less confident in their abilities, lack of trust if they are able to succeed and happy (Zakeri \& Karimpour, 2011). While in the aspect of learning result success, authoritarian parenting is known to be better than permissive parenting. But democratic parenting is significantly correlated with academic achievement index. On the other hand, other studies also mention that the reason for students' academic success is not necessarily seen through the influence of parenting, but there are other influences. Academic success is also seen from the consistency of the parenting styles and order of both parents (Inam, Nomaan, \& Abiodullah, 2016; Oliveira, 2015).

\section{CONCLUSION}

In this study, the questioning skills possessed by the teacher, the students' responses to the teacher's questions, and the parenting style that the students have had been studied. Based on the results of this study, the skill to ask the question of elementary school teachers in Batam was good enough. Student responses to teacher questions indicated that: (a) student answers categories were dominated by scientific answers, half scientific, zero and wrong; (b) not many students could not answer (when the teacher asked all students); (c) students gave more answers simultaneously; (d) few students were appointed but unable to answer; (e) many designated students were able to answer; (f) students were confused to give the right answers to practical learning, and (g) few students showed themselves to answer questions and few students asked a question to the teacher. Furthermore, the findings student responses suggested that authoritarian parenting (94.83\%) has 
produced children who are less confident in their abilities, lack of trust if they will be successful and happy in the future.

Skills in giving questions are important factors in the learning process. Teachers in Batam have good skills, but advanced questioning skills still need to be improved. Students must also be encouraged to dare to answer teacher questions so that students' responses in answering questions are better. Furthermore, parents as factors that play a role in learning success students must have a parenting style that does not emphasize their personal desires.

\section{ACKNOWLEDGMENT}

The researcher delivered their deepest gratitude to the Ministry of Research, Technology, and Education of the Republic of Indonesia for granting full fund for this study. Further gratitude was sent to the entire academic community of the Teaching and Education Faculty of Universitas Kepulauan Riau, teachers and students of Batam City Elementary School, State Elementary School 008 of Batam, as well as State Elementary School 11 and 21 of Sagulung District.

\section{REFERENCES}

Almeida, P. A. (2012). Can I ask a question? the importance of classroom questioning. In Procedia - Social and Behavioral Sciences (Vol. 31, pp. 634-638). doi: https://doi.org/10.1016/j.sbspro.2011.12.116

Bacus, M. P. (2014). Parenting styles, self-concept and attitude of students: A causal model on academic performance. In International Conference on Economics, Social Sciences and Languages (pp. 93-97). Singapore. doi: https://doi.org/10.15242/ICEHM.ED0514054

Baugh, E., \& Davis, C. (2016). The influence of perceived parenting style and contraceptive self-efficacy on college student contraceptive use. Marriage \& Family Review, 52(8), 764-780. doi: https://doi.org/10.10 80/01494929.2016.1157558

Bulent, D., Erdal, B., Ceyda, A., Betul, T., Nurgul, C., \& Cevahir, D. (2016). An analysis of teachers questioning strategies. Educational Research and Reviews, 11(22), 2065-2078. doi: https://doi.org/10. 5897/ERR2016.3014

Çakır, H., \& Cengiz, Ö. (2016). The use of open ended versus closed ended questions in Turkish classrooms. Open Journal of Modern Linguistics, 06(02), 60-70. doi: https://doi.org/10.4236/ojml.2016.62006

Çakmak, M. (2009). Pre-service teachers 'thoughts about teachers' questions in effective teaching process. Education, 8(3), 666-675. Retrieved from http://ilkogretim-online.org.trlindex.php/io/article/viewFile/192 5/1761

Etemadzadeh, A., Seifi, S., \& Far, H. R. (2013). The role of questioning technique in developing thinking skills: The ongoing effect on writing skill. Procedia - Social and Behavioral Sciences, 70, 1024-1031. doi: https ://doi.org/10.1016/j.sbspro.2013.01.154

Fashiku, C. O. (2017). Effective communication: Any role in classroom teaching - Learning process in Nigerian schools? Bulgarian Journal of Science and Education Policy, 11(1), 171-187. Retrieved from https://search. proquest.com/docview/1916639835?accountid=62722

Hamiloglu, K., \& Temiz, G. (2012). The impact of teacher questions on student learning in EFL. Journal of Educational and Instructional Studies in the World of Educational and Instructional Studies in the World, 2(2), 1-8. Retrieved from http://www.wjeis.org/FileUpload/ds217232/File/01.hamiloglu.pdf

Hanum, N. S. (2016). The importance of classroom interaction in the teaching of reading in junior high school. In Seminar Nasional Pengembangan Profesinalisme Pendidik untuk Membangun Karakter Anak Bangsa (pp. 1-9). Malang: Universitas Negeri Malang. Retrieved from http://pasca.um.ac.id/confe rences/index.php/gtk/article/view/326/309

Inam, A., Nomaan, S., \& Abiodullah, M. (2016). Parents' parenting styles and academic achievement of underachievers and high achievers at middle school level. Bulletin of Education and Research, 38(1), 57-74. Retrieved from http://pu.edu.pk/images/journal/ier/PDF-FILES/5_Attiya, Sara \& Abiodullah_v38 12016.pdf

Ishak, Z., Low, S. F., \& Lau, P. L. (2012). Parenting style as a moderator for students' academic achievement. Journal of Science Education and Technology, 21(4), 487-493. doi: https://doi.org/10.1007/s10956-0119340-1

Kenney, S. R., Lac, A., Hummer, J. F., Grimaldi, E. M., \& LaBrie, J. W. (2015). Pathways of parenting style on adolescents' college adjustment, academic achievement, and alcohol risk. Journal of College Student 
Retention: Research, Theory \& Practice, 17(2), 186-203. doi: https://doi.org/10.1177/152102511557823 2

Kim, S. (2015). An analysis of teacher question types in inquiry-based classroom and traditional classroom settings. University of Lowa. Retrieved from https://search.ebscohost.com/login.aspx?direct=true \&db=eric\&AN=ED567634\&site=ehost-live\%0Ahttp://gateway.proquest.com/openurl?url_ver=Z39.88-200 4\&rft_val_fmt=info:ofi/fmt:kev:mtx:dissertation\&res_dat=xri:pgm\&rft_dat=xri:pqdiss:10016515

Lee, B.-M., Kang, D.-W., Jung, C.-H., Choi, J.-H., Hwang, I.-T., Hong, S.-K., \& Lee, J.-S. (2011). Patterning of polymer nanocomposite resists containing metal nanoparticles by electron beam lithography. Journal of Nanoscience and Nanotechnology, 11(8), 7390-7393. doi: https://doi.org/10.1166/jnn.2011.4803

Nalole, M. (2010). Kemampuan guru menerapkan ketrampilan bertanya pada pembelajaran matematika di kelas IV SDN No. 64 Kota Timur Kota Gorontalo. Inovasi, 7(2), 33-43. Retrieved from http://ejurnal. ung.ac.id/index.php/JIN/article/view/778

Napp, J. S. (2017). The importance of questioning in developing critical thinking skills. International Journal for Professional Educators, 84(1), 30-41. Retrieved from https://cpb-us-e1.wpmucdn.com/cobblearning.net/ dist/6/3101/files/2018/05/The-Importance-of-Questioning-2aqkc5j.pdf

Necşoi, D. V., Porumbu, D., \& Beldianu, I. F. (2013). The relationship between parental style and educational outcomes of children in primary school in Romania. In Procedia - Social and Behavioral Sciences (Vol. 82, pp. 203-208). doi: https://doi.org/10.1016/j.sbspro.2013.06.246

Oliveira, T. L. B. De. (2015). Are associations between parenting style and academic achievement moderated by ethnicity and individualism-collectivism? Dissertation Abstracts International: Section B: The Sciences and Engineering. Walden University. Retrieved from https://scholarworks.waldenu.edu/cgi/ viewcontent.cgi? referer=https://www.google.com/\&httpsredir=1\&article=1511\&context=dissertations

Omar, O. (2009). Teachers' questioning techniques and their potential in heightening pupil's inquiry. In International Conference on Primary Education 2009 (pp. 1-18). Hong Kong. Retrieved from https:/l www.eduhk.hk/primaryed/eproceedings/fullpaper/RN354a.pdf

Ragawanti, D. T. (2010). Questions and questioning techniques: A view of Indonesian students' preferences. K@ta, 11(2), 155-170. doi: https://doi.org/10.9744/ing.v11i2.17891

Robinson, C. C., Mandleco, B., Olsen, S. F., \& Hart, C. H. (1995). Authoritative, authoritarian, and permissive parenting practices: Development of a new measure. Psychological Reports, 77(3), 819-830. doi: https://doi.org/10.2466/pr0.1995.77.3.819

Toldson, I. A., \& Lemmons, B. P. (2013). Social demographics, the school environment, and parenting practices associated with parents' participation in schools and academic success among Black, Hispanic, and White students. Journal of Human Behavior in the Social Environment, 23(2), 237-255. doi: https://doi.org/10.1080/10911359.2013.747407

Warren, J. M., Locklear, L. A., \& Watson, N. A. (2018). The role of parenting in predicting student achievement: Considerations for school counseling practice and research. The Professional Counselor, 8(4), 328-340. doi: https://doi.org/10.15241/jmw.8.4.328

Yang, H. (2017). A research on the effective questioning strategies in class. Science Journal of Education, 5(4), 158. doi: https://doi.org/10.11648/j.sjedu.20170504.16

Yazdani, S., \& Daryei, G. (2016). Parenting styles and psychosocial adjustment of gifted and normal adolescents. Pacific Science Review B: Humanities and Social Sciences, 2(3), 100-105. doi: https://doi.org/10.1016/j.psrb.2016.09.019

Zakeri, H., \& Karimpour, M. (2011). Parenting styles and Self-esteem. In Procedia - Social and Behavioral Sciences (Vol. 29, pp. 758-761). Elsevier B.V. doi: https://doi.org/10.1016/j.sbspro.2011.11.302

Ziyaeemehr, A. (2016). Use of questioning techniques and the cognitive thinking processes involved in student-lecturer interactions. International Journal of Humanities and Cultural Studies, 3(1), 1427-1442. Retrieved from http://www.ijhcs.com/index.php/ijhcs/article/download/1432/1304 